\title{
A high iodine intake, thyroid diseases and the prevalence of papillary carcinoma (PTC)
}

\author{
George Zhu* \\ The Institute of Oncology, Tehran University of Medical Sciences, Tehran, Iran
}

\begin{abstract}
Iodine is a trace element that is essential for the synthesis of thyroid hormone. Both chronic iodine deficiency or iodine excess have been associated with hypertrophy and hyperplasia of follicular cells and the influence of thyroid hormone (T3, T4) and thyrotropin (TSH) secretion. Increase rates of the thyroid cancer are increasing after radiation exposure to $131 \mathrm{I}$ in children or adolescents. In respectively, dietary iodine excess goiter, iodine induced hyperthyroidism (IIH) and IIT, Iodine intake and the prevalence of papillary carcinoma (PTC), as well as the case-control and cohort studies of thyroid cancer and intake of seafood and milk products, were reviewed. Moreover, available evidence of oncogenic thyroid hormone receptor mutants from animal experiments and clinical investigation have been a shift toward the oncogenic function of human thyroid carcinoma, and its target therapy.
\end{abstract}

\section{Introduction}

The main function of the thyroid gland is to make hormones (Figure 1) [1], T4 and $T 3$, which are essential for the regulation of metabolic effects for instance increased lipogenesis, ketogenesis, and cellular proliferation and differentiation such as the rapid development of frogs from thyrectomized tadpoles, the induction of growth hormone in the pituitary and the development of the brain in neonatal by promoting dendrite formation and myelination.

Iodine is a trace essential raw element where $65 \%$ of $\mathrm{T} 4$ weight is iodine [2]. Ingested iodine is absorbed and carried in the circulation as iodide. Intracellular iodide across the plasma membrane of thyrocytes by the sodium/iodide symporter is transported in the lumen of thyroid follicles. Meanwhile, the thyrocyte endoplasmic reticulum synthesizes two key proteins, TPO (thyroperoxidase) and Tg (thyroglobulin). Tg is a $660 \mathrm{KDa}$ glycoprotein secreted into the lumen of follicles, whose tyrosyles serve as substrate for iodination and hormone formation. TPO sites at the apical plasma membrane, where it reduces $\mathrm{H} 2 \mathrm{O} 2$, elevating the oxidation state of iodide to an iodinating species, and attaches the iodine to tyrosyls in $\mathrm{Tg}$. $\mathrm{H} 2 \mathrm{O} 2$ is generated at apex of the thyrocyte by Duox, a NADPH oxidase. Initial iodination of Tg products MIT and DIT. Further iodination couples two residues of DIT produce T4 at residues 5 in the Tg polypeptide chain (Figure 2). After Tg digestion, $\mathrm{T} 4$ and T3 are released into circulation. Nonhormonal iodine is retrieved intrathyroidally by DEHAL1, an iodotyrosine deiodinase and made available for recycling within the gland. Iodine supply, either too much or too little, impairs adequate synthesis of thyroid hormone. According to WHO/UNICEF/ICCIDD [3,4], daily iodine intake is $90 \mathrm{ug}$ for infants and young children (0-59 months), $120 \mathrm{ug}$ for children 6-12 years, $150 \mathrm{ug}$ for adolescents and adults, and $250 \mathrm{ug}$ for pregnant and lactating women. In this paper, considering that iodinedeficiency endemic goiter and deficiency of thyroid hormone synthesis and secretion (Cretinism) and defective thyroid hormone receptor alpha are well clinical established and readily understandable, we are deliberating the topic entity of iodine excess induced thyroid diseases and papillary carcinoma (PTC).

\section{Induction of thyroid neoplasm in rat}

In rats development of thyroid neoplasm following radioactive iodine was well established in earlier comparative experiments in 1950-1964 last century [5-8]. Recent, thyroid tumor-promoting effects of iodine deficiency and excess have also been investigated in two-stage models in rats given carcinogens, such as $\mathrm{N}$-bis (2-hydroxypropyl)nitrosamine (BHPN) or N-nitrosomethylurea (NMU). In rats exposure to $\mathrm{N}$-nitrosobis (2-hydroxypropyl) amine (BHP) and an excessive iodine diet [9], the incidence of thyroid cancer was $29 \%$ in those fed the excessive iodine diet versus $33 \%$ in those fed the iodine sufficient diet. Kanno, et al. [10] examined the potential thyroid tumorpromoting effects of iodine deficiency and excess for 26 weeks in rats given saline or BHPN. In saline-treated rats, iodine deficiency or excess alone was not carcinogenic, but in BHPN-treated rats, both iodine deficiency and excess increased thyroid follicular tumors, with iodine deficiency having a markedly stronger effect (Figure $3 \mathrm{a}$ ). The incidence of rats with benign nodules was $100 \%$ in both group. Boltze [11] fed rats over a period of 110 weeks high ( 10 fold of normal), normal, and low ( $\sim .1$ fold of normal) daily iodine intake and subjected them to single external radiation of 4 gray (Gy) or sham radiation. Alone, both iodine deficiency and excess increased the thyrocyte proliferation rate and induced thyroid adenomas, but induced no thyroid carcinomas. Combined with radiation, both iodine deficiency and iodine excess induced thyroid carcinomas (PTC and follicular thyroid carcinomas, FTC) in $50-80 \%$ of animals, while iodine sufficient animals did not develop thyroid carcinomas (Figure $3 \mathrm{~b}$ ). These data suggest both longterm iodine deficiency and excess are insufficient to stimulate thyroid

Correspondence to: George Zhu, The Institute of Oncology, Tehran University of Medical Sciences, Tehran, Iran, E-mail: sansan4240732@163.com

Key words: iodine excess goiter, IIH and IIT, the pattern of papillary carcinoma (PTC), oncogenic thyroid hormone receptor mutants

Received: November 22, 2017; Accepted: December 27, 2017; Published: December 30, 2017 


\section{Thyroid hormone biosynthesis}
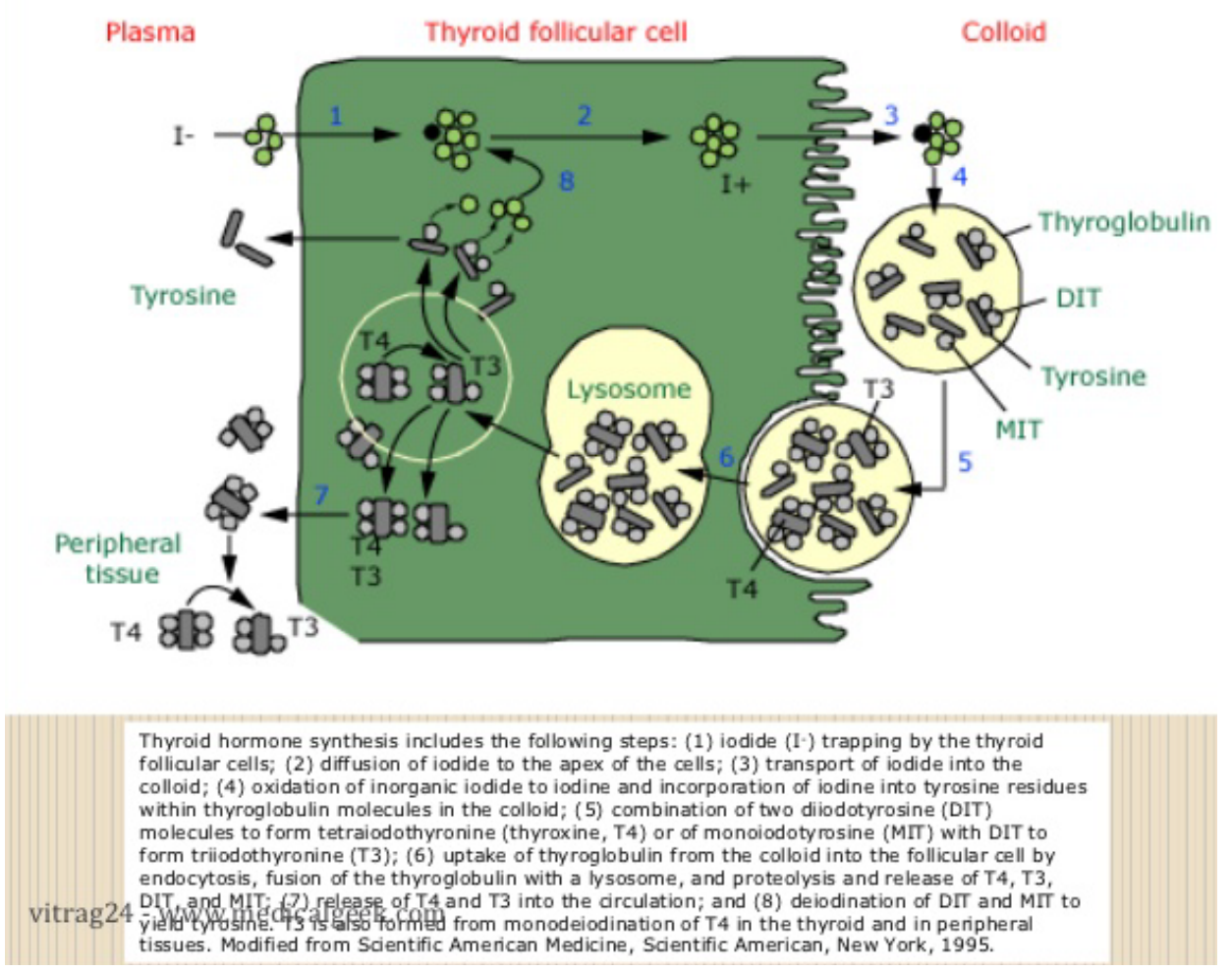

Figure 1. Thyroid hormone biosynthesis

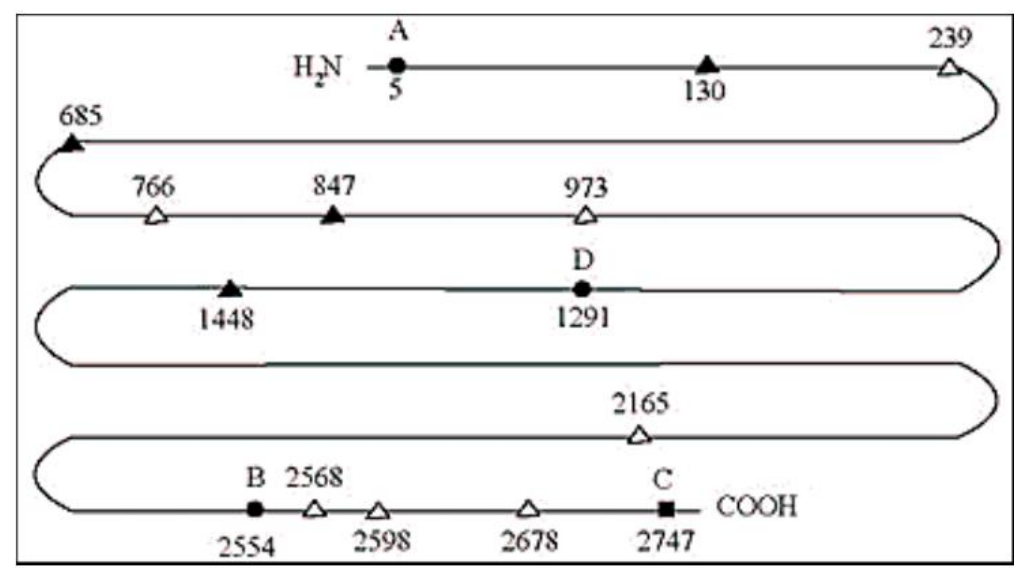

Figure 2. Iodination of T4 at residue 5 in the Tg chain (Data from Rousset, et al. [4])

carcinogenesis, but both promote thyroid carcinogenesis induced by radiation. These less convincing evidence suggest that iodine excess may be a weak promoter of thyroid cancer.

Prevalence of animals with thyroid adenoma and thyroid carcinoma at week 26 after a single $2.8 \mathrm{mg} / \mathrm{kg}$ DHPN dose at week 2 and under one of seven long-term deficient, sufficient or excessive iodine diets (deficient intake: $0.25,0.4,0.55,0.84 \mu \mathrm{g} / \mathrm{day}$; normal intake: $2.6 \mu \mathrm{g} /$ day; excessive intake: 760, $3000 \mu \mathrm{g} /$ day). b Prevalence of animals with thyroid adenoma and thyroid carcinoma at week 110 after a single exposure to 4-Gy external radiation at week 6 and under one of three long-term deficient, sufficient or excessive iodine diets (deficient intake: $0.42 \mu \mathrm{g} / 100 \mathrm{~g}$ body weight/day; normal intake: $7 \mu \mathrm{g} / 100 \mathrm{~g}$ body weight/day; excessive intake: $72 \mu \mathrm{g} / 100 \mathrm{~g}$ body weight/day). Shaded area: range of normal iodine intake (Data from Zimmermann MB, et al. [12]).

\section{Radiation exposure and risk of thyroid cancer in man}

External radiation to the thyroid increases risk of thyroid cancer, particularly when the radiation occurs in children or adolescents [1220]. The Chernobyl nuclear accident in 1986 exposed population of Belarus, Ukraine, and the Russian Federation to internal radiation from radioactive iodines deposited in the thyroid, resulting in sharp 

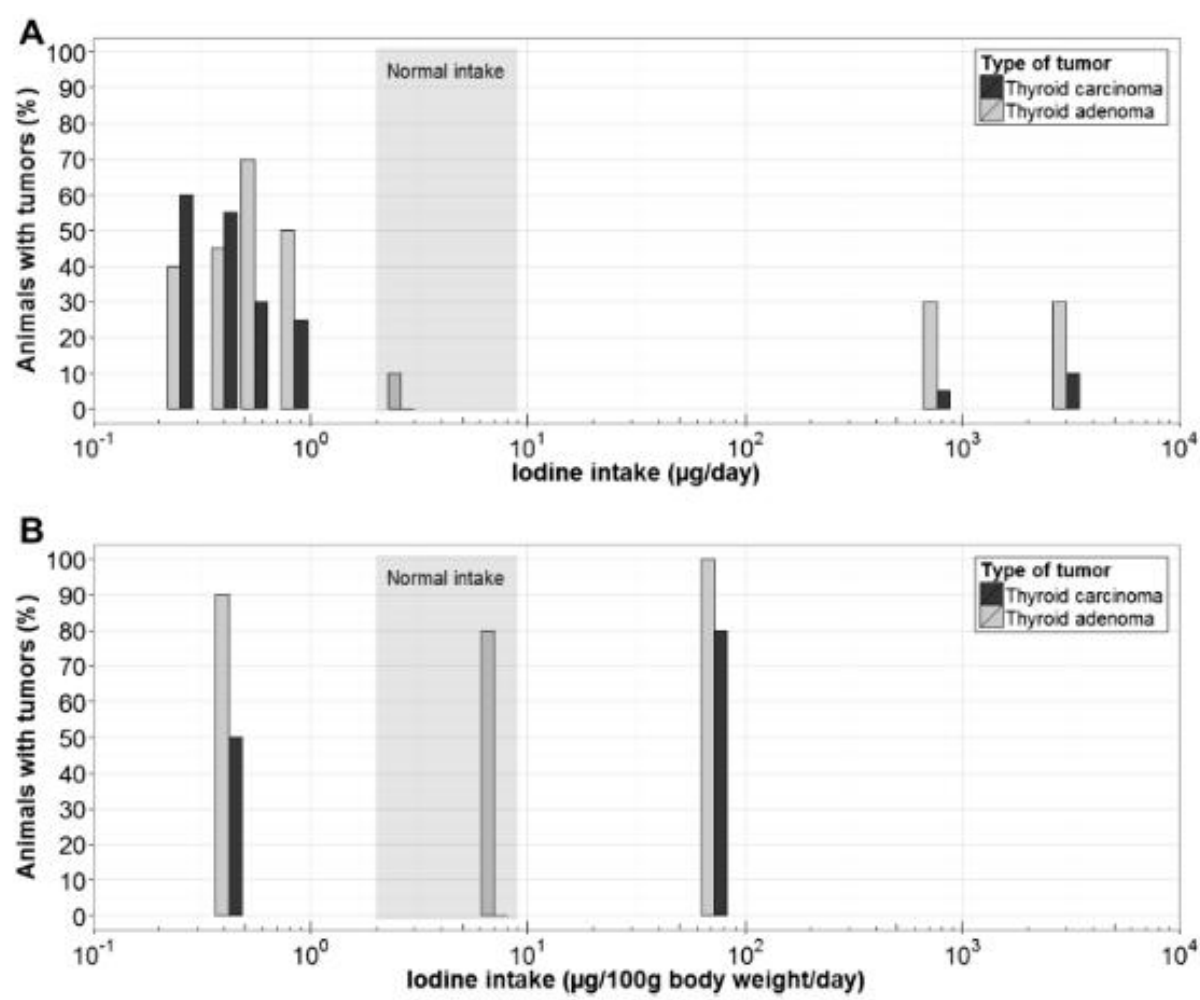

Figure 3. Prevalence of tumors in animals versus iodine intake

increase in pediatric and adolescent thyroid cancer [18]. About $60 \%$ of the Belarusian thyroid cancer and $30 \%$ of the Ukrainian cases, mainly PTC, were identified about 20 years after the accident [21]. Historically, the areas exposed to Chernobyl fallout were affected by varying degrees of past iodine deficiency [22]. Chronic iodine deficiency increases thyroidal clearance of plasma iodine, increases thyroid blood flow and thyrocyte proliferation, and increases thyroid size, all of which may increase thyroid uptake of ingested radioiodines, also thereby increasing vulnerability of thyroid to the accumulated radioiodines $[15,23]$. A history of goiter was associated with the risk of thyroid cancer (OR 2.19), but the study had limited due to a small number of cancer cases $(n=45)[17,20]$.

\section{Iodine excess goiter - A diverse etiological subtype of goiter}

In the 7-9-year-old, the median value of thyroid volume was $4.7 \mathrm{ml}$ (normal children 4.0-4.8 ml) [24]. The main finding of close correlation between increased in thyroid volume and high iodine intake in children is based mainly on data from coast Hokkaido in 1962-69. The incidence of endemic coast goiter among students had $6.8 \%$ to $8.9 \%$, but never been documented to be $>25 \%[25,26]$. Niepominszoze [27] examined the epidemiology of palpable goiter at the population of the metropolitan area of Greater Buenas Aires (11 million inhabitants), an iodine sufficient area. In the Random Group, goiter prevalence of $8.7 \%$ while in the Induced Group, which conclude among relatives of patients with thyroid disorders and other complaints, it climbed to $14.4 \%$. Both group were mostly made up of women $(87.2 \%)$. The epidemic data presented the fist arising from a screening survey carried out in a large iodine-sufficient population of the Southernmost of the American Continent.

To study the effect of excess iodine and excess tyrosine on goiter in mice [28], high iodine feed (high iodine and adequate tyrosine, HIAT) could result in the typical colloid goiter in mice and the goiter rate was
$89.5 \%$ whereas $35 \%$ of goiter was observed in both iodine and tyrosine excess (HIHT), and no goiter was noted in only high tyrosine (AIHT) (Figure 4), which implicate that both iodine and tyrosine played important role in goiter, with iodine excess having a markedly stronger effect, and which characterized by large follicles with flat epithelium and abundant colloid mixed with normal or larger-sized follicles lined by epithelium of increased thyroid weight. Moreover, there existed positive association between goiter rate of mice and iodine (KI) doses [29]. The differential goiter rate of $10 \%, 50 \%$ and $90 \%$ could be induced by drinking water containing different iodine doses accordingly 250 , 1500 and $3000 \mathrm{ug} / \mathrm{L}$ respectively. The dose of iodine $250 \mathrm{ug} / \mathrm{l}$ was able to induce colloid goiter in mice. The findings were compatible with the epidemiologic results by authors in man. Iodine content in drinking water was $244.63,533.83,963.75$ and $1570.0 \mathrm{ug} / \mathrm{l}$ versus $6.4 \%, 32.4 \%$, $37.14 \%$ and $43.71 \%$ of goiter respectively [29].

Accumulated data, in the past decades, there have been at least 46 reported cases of goiter in man associated with iodine (K I, Na I, Lugol solution and antiarrhythmic agent amiodarone). From epidemiology, in China, there were $16 \%$ rate incidence of iodine goiter for tangle salt diet (iodine content $1089.2 \mathrm{ug} / \mathrm{kg}$ ); and $28.36 \%$ (total 4344 analyses) rate incidence of iodine goiter in higher iodine drinkers from deep well water (iodine content $661.2 \mathrm{ug} / \mathrm{L}$ ) compared to $8.37 \%$ (4158) of goiter in low iodine water drinker (iodine content $27.2 \mathrm{ug} / \mathrm{L}$ ) [30]. In china, children's goitet rate in excessive iodine regions with iodized salt was higher than that of without iodine salt $12.1 \%$ vs. $8.6 \%$ [31]. In Jinan, among 725 inhabitant's investigations, thyroid goiter rate was $4.8 \%$ (35/725). The UIC (urinary iodine concentration) in 725 subjects from $29 \mathrm{rural}$ areas were $327.0 \mathrm{ug} / \mathrm{l}$ (range 35-2938.5 ug/l), and water iodine content from 376 samples of drinking water $112.1+/-91.3 \mathrm{ug} / \mathrm{l}$ in mean, $90.3 \mathrm{ug} / \mathrm{l}$ (range 0.5-605.2 ug/l in medium) [32]. Table 1 presented partly the occurrence rate of coast goiter as below. 
Table 1. Iodine excess endemic goiter in coast, China (Data from Yu ZH, et al. [30])

\begin{tabular}{|c|c|c|c|c|c|}
\hline Year & Province & Rural areas & Water iodine (ug/l) & Urine iodine (ug/l) & Goiter crude incidence (\%) \\
\hline \multirow[t]{2}{*}{1978} & Hebei & Bohai Bay & 661.2 & & 28.36(total 4344 analyses) \\
\hline & & & 27.2 & & $8.37($ total 4158$)$ \\
\hline \multirow[t]{2}{*}{1983} & Shandong & Bohai Bay & $1272-1920$ & & $50-70$ \\
\hline & & Rizhao & 1089.2 & & 16.0 \\
\hline 1983 & Xinjiang & Kuitunwusu & $66-2375$ & & 8.0 \\
\hline 1986 & Shanxi & Xiaoyi & 533.8 & 2428.5 & 32.54 \\
\hline 1987 & Fukien & Tongan & $290.0-584.0$ & 849 & 32.84 \\
\hline 1993 & Henan & Guiqian & 1059.8 & 924.9 & 22.4 \\
\hline 1994 & Inner Mongolia & Shiyouqi & $380-1757$ & 1151.7 & 10.84 \\
\hline \multirow[t]{2}{*}{1997} & Jiangsu & Huashan & $520-1875$ & 931.5 & 23.9 \\
\hline & & Zhangjiazhuang & $397-6403.3$ & & 11.5 \\
\hline 1999 & Beijing & Daxing & $337.1-698.6$ & 586.7 & 11.9 \\
\hline
\end{tabular}

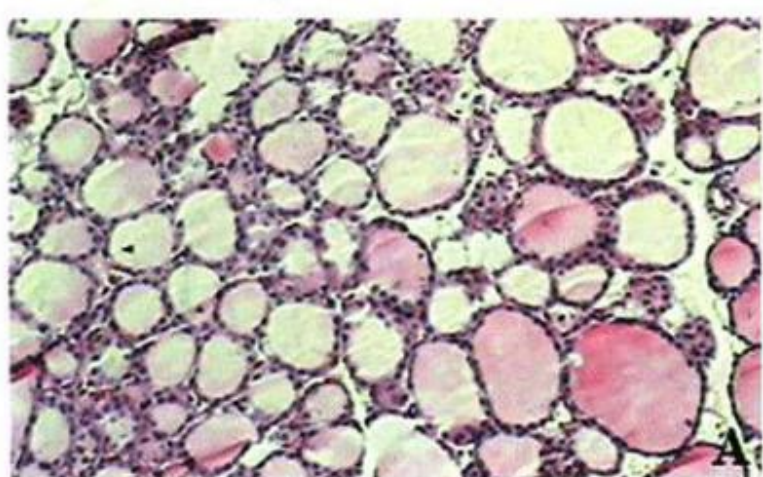

A. AIAT

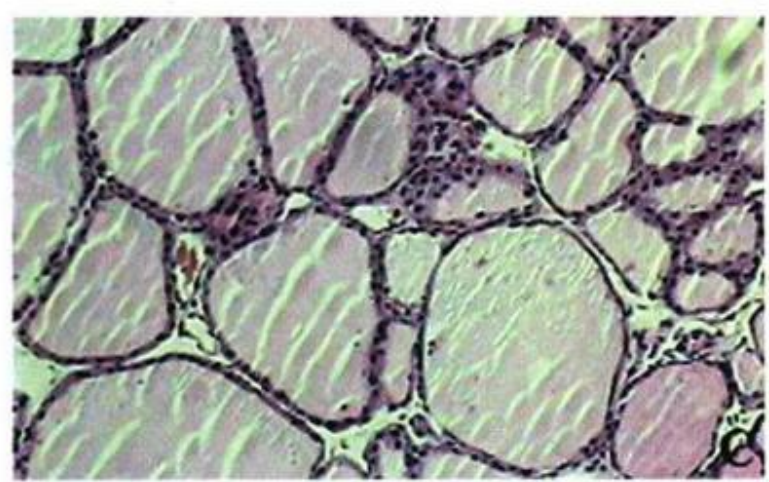

\section{HIAT}

Figure 4. High iodine induced goiter in rat model (Data from Li N [28])

\section{Iodine induced hyperthyroidism (IIT) and thyrotoxicosis (IIT)}

According to WHO above in 1994 [33] and the Korea Centers for disease control and prevention (KCDC) in 2012 (34)] food products such as processed, agricultural, meats, and marine products were monitored for measuring dietary iodine. The recommended iodine daily allowance of 70-150 ug [35]. An excess of iodine through dietary intake, drugs or other iodine-containing compounds can lead to goiter [36,37], hyperthyroidism [38-45], hashimoto's thyroiditis [46] and thyrotoxicosis [47-54] through increasing thyroid hormone synthesis in the presence of underlying thyroid disease, particularly multinodular goiters containing previously existing area of autonomous function. In 1958, Introduction of potassium iodide (KI) in order to the prevention of goiter in French, many students developed iodine goiter with oral high dosage of $1 \% \mathrm{KI}$ or $10 \mathrm{mg}$ KI daily. Until now, in literature, there were at least 22 cases reports on IIH or IIT. Potassum iodide (KI) at 10-4--10-7 mol/L concentration stimulate the proliferation of thyroid cancer BPH 10-3 cells, increased levels of serum T3 and T4, increased cyclin D1 mRNA and protein (Nie, 2005; Li, 2013). In rats serum thyroxine (TT4, FT4, rT3) was higher in higher iodine than the result in lower iodine (Nie, 2005).

Iodine-induced hyperthyroidism (IIH) has been frequently described when iodine is introduced into an iodine-deficient area [38], patients residing in iodine-sufficient areas [43] and iodinated preparation for water purification [40]. Excessive iodine intake might also be due to a long-term topical exposure (iodine solution dressing or topical iodine application) or by intravenous administration of iodine-containing substances $[39,41,45,55]$. In a classical study, four euthyroid patients with a single autonomous nodule from the slightly iodine-deficient Brussels region received a supplement of 500 ug iodine per day. This caused a slow but constant increase of thyroid hormone. After four weeks, the patients became hyperthyroid [47]. Therefore, individuals with multinodular goiters living in iodine-replete regions can also develop hyperthyroidism, confirming that nodular goiters are particularly prone to developing IIT [48]. Iodine-induced IIT was recognized as early as 1821 by Coindet [40], who reported that goitrous individuals treated with iodine developed hyperthyroidism. Comparative survey of thyrotoxicosis epidemiology in East-Jutland Denmark and Iceland, it occurs that high incidence of multinodular toxic goitre in the elderly population in a low iodine intake area whereas high incidence of Grave's disease in young in a high iodine intake area [56]. In northern Tasmania in UK, in 1964 and in 1971 respectively, the incidence of thyrotoxicosis rose substantially because of the addition of iodate to bread to prevent goitre or iodine residues in milk [51]. In Vigo, Spain, dietary of iodine supplementation in iodine sufficient areas may induce the increase of thyrotoxicosis (TT) (7.68/100,000), as opposed to $3.1 / 100,000$ in area without iodized salt [57]. IIT has been reported after initiating iodine supplementation, also with use of iodinated drugs, radiographic contrast agents and food dietary iodine [48-58] (Table 1). Table 1 present iodine-containing compounds related to IIT.

Table 1. Iodine-containing compounds potentially associated with IIT

Radiological contrast agents: Diatrizoate, Ipanoic acid, Ipodate, Iothalamate, Metrizamide, Iopromide, Iopamidol, Iotrolan

Topical iodine preparation: Iodine tincture, povidone iodine (Betadine), Iodoform gauze

Solution: Saturated potassium iodide, Lugol solution, iodinated glycerol (organidin), echothiopate iodide, hydriodic acid syrup 
Drugs: Amiodarone, vitamins containing iodine, potassium iodide, Isopropamide iodide

Food components: kelp, kombu and other marine algae, iodine compounds in bread, Hamburger thyroiditis

Amiodarone is the most common source of iodine in the United States. Amiodarone-induced thyrotoxicosis (AIT) type I results from iodine increase in thyroxine synthesis $(200 \mathrm{mg}$ of amiodarone containing $75 \mathrm{mg}$ of iodine). Patients developing AIT type I usually have a preexisting nodular goiter. AIT type II is caused by cytotoxic effects of medication that results in the release of preformed thyroxine [48]. AIT occurs late after amiodarone withdrawal [59].

Kelp are large seaweeds, belonging to the brown algae and classified in the order Laminariales, and are an important food source in many Asian cultures [60]. The average iodine content of kelp of 1,500 to $2,000 \mathrm{ug} / \mathrm{g}$ was measured $[61,62]$. Herbal medicine, including kelp and kelp-containing dietary supplements, are also used by an increasing number of patients [63]. Suzuki [23] was the first to report a case of endemic seashore goiter following marine algae. At present there have been reported at least 8 patients with IIH or IIT after ingestion of kelp [60,64-69]. Another 12-thyrotoxicosis caused by weightreducing herbal medicine [63]. In 2001, Zhu [70] reported a case of thyroid neoplasm following marine algae in a breast cancer. From epidemiologic studies in Korean population, high intake of iodine from marine products may increase thyroid cancer risk, particularly in women [71,72]. Accumulated data, seaweed accounts for about $80 \%$ of Japanese people's iodine intake, seaweed consumption was clearly associated with an increased risk of papillary carcinoma (PTC) in postmenopausal women [73].

\section{Dietary iodine intake and the prevalence of papillary carcinoma (PTC)}

Thyroid neoplasia can result from many different causes. These include low iodine diets, radioactive iodine and natural goitrogens. Dietary iodine intake act as a potential relevance risk factor of thyroid cancer [21,71-76]. Elevated incidence and mortality rate of thyroid cancer have been found in areas where iodine intake is high (Howaii, Iceland) [76-78]. In South India, among 300 patients with goiter and 100 euthyroid health non-goitrous volunteers, iodine-induced hyperthyroidism or IIT (34\%) and thyroid cancer (15\%) have been observed after continued supplement of edible salt fortified with excess iodine [79]. In China, using comparative analysis of 4679 postoperative patients with universal salt iodization (USI) during 19942008 and 3325 post-operative patients without USI during 1979-1993, the incidence ratio of thyroid carcinoma after USI was 5.6\% (308/4679) compared to $2.9 \%$ (95/3325) in patients without USI, 32.7\% (1530) of thyroid adenoma after USI compared to $20 \%$ (665) before USI, and $4.5 \%$ (212) of toxic goiter after USI compared to $2.7 \%$ (95) before USI [80]. According to 1101 thyroid malignant tumors confirmed by pathological specimens, constitional ratio of PTC (70.17\%) increased obviously after USI compared with the results $(55.84 \%)$ before USI whereas the proportion of FTC (11.05\%) decreased accordingly after USI compared with the results $(24.58 \%)$ before USI [81]. The same results were also reported based on 429 analyses [82]. The prevalence of PTC (80-90\%) in thyroid carcinoma increased significant after USI. In Shengyang, china, the ratio of PTC: FTC was from 2.3 to 21.9 before and after salt iodization. Therefore, in the presence of sufficient iodine intake, more than $80 \%$ of thyroid cancer consisted of papillary carcinoma (PTC), whereas in area with iodine-deficiency, in contrast, have a higher incidence of FTC (Figure 5, Giusti [83]). Compared with matched controls, urinary excretion of iodine excess was detected in 302 cases of thyroid benign tumors (519 ug/L) and 240 thyroid cancers (524 ug/L) (Liu, 2008). Higher urine iodine was associated with PTC (urine iodine:355.3+/-289.6 ug/L in 53 PTC, Zhou, 2014)

And more, According to Zimmerann in recent review [12] and Williams the earlier review [22], there were reports that in countries with 'high' iodine intake (US, Iceland) the ratio of PTC: FTC ranged from 3.4 to 6.5 , while in countries with 'moderate' iodine intake (the UK and northern Germany) the ratio was from 1.6 to 3.7 , and in countries with 'low' iodide intake (Argentina, Columbia, Finland, Southern Germany, Austria and Switzerland) the ratio was from 0.19 to 1.7. The incidence of PTC in the Netherlands has increased by $2.1 \%$ per year between 1989 and 2003, which was partly explained by the stable and sufficient iodine intake of the Dutch population during the last 4 decades, together with other low level of radiation exposure and incidentally discovered thyroid nodules [84]. In northwestern Spain, iodized salt was introduced in 1985, the thyroid cancer incidence increased in females from $1.56 / 100,000$ during $1978-1985$ to $8.23 / 100,000$ in peroid from 1984 to 2001, the PTC: FTC increased from 2.3 to 11.5 [85]. Italy had one of the highest incidence rates for thyroid cancer, nearly $20 / 100,000$ women in 2007, the frequency of thyroid cancer in females with cold nodules was $5.3 \%$ in the iodine sufficient area (mean UIC $114 \mathrm{ug} / \mathrm{l}$ ) and $2.7 \%$ in the iodine deficient area (mean UIC $<50 \mathrm{ug} / \mathrm{l}$ ) [86]. The highest incidence rates for thyroid cancer are Japan, where iodine intake is high [22]. Occult thyroid cancer (OTC) was more common in glands with nodular goiter (range 15.7\% 28.4\%) in areas of excessive iodine intake [87-90]. A case-control study in Hawaiian adults reported the association between dietary iodine intake and thyroid cancer in 191 cases (85\% PTC) and 442 controls [91]. But increasing thyroid cancer rates were not been associated with national iodine intake according to UIC data from US population [92,93], Sweden [94] and Denmark $[95,96]$. Overall, in the past 2 to 3 decades, there is clear temporal relationship in many countries between introduction of iodized salt and an increase in incidence of PTC [83,97-100] (Figure 5)

In case-control studies, cruciferous plants were found an association with increased thyroid cancer risk. In epidemiology, in Sweden, the risk of thyroid cancer associated with a high cruciferous vegetable intake was higher among female who had ever lived in an endemic goiter area [101]. In Poland, frequent cruciferous vegetable consumption was associated with a 1.5 -fold increase in the risk of thyroid carcinoma [102]. However, A study from New Caledonia among Melanesion women who consume large quantities of cruciferous vegetables, and low iodine intake ( $<96.0 \mathrm{ug} /$ day) showed a positive association [103]. The study from Kuwait, high intake of cabbage showed an increased risk with a borderline significance [104]. Thus, in this area, more accumulated results are needed to be testable.

Overall, the findings indicated clearly carcinogenesis of I131 or/ and radiogenic transformation on thyroid glands in the rats and man. Dietary iodine intake is another care of environmental relevance factor in thyroid diseases and papillary carcinoma.

\section{Oncogenic thyroid hormone receptor mutants}

It has been demonstrated that thyroid status had a modulating effect on neoplasia. Like iodine- induced hyperthyroidism and IIT, using thyroxine L-T4 which $65 \%$ of T4 weight is iodine, Ciosek [105] induced experimental model of rat hyperthyroidism. Administration of thyroid hormone to thyrectomized rodents is a prerequisite for the induction of hepatomas by chemicals, indicating a role in the initiating action of carcinogen [106]. This thyroid hormone (T3) signaling through 
thyroid hormone receptor (THRa1) regulates hepatoma cell growth [107]. In literature, there have been more 10 cases of earlier reports on the thyroid carcinomas and concurrent hyperthyroidism (Grave's disease), and also concurrent toxic nodular goiters [108-110]. The other 11 cases were further reported [111,112]. Among10 hyperthyroidism, of whom 6 with Grave's disease complicated with thyroid cancer, 2 hyperthyroidisms with thyroiditis and thyroid cancer [111]. Another case was reported in a 43-old-man with initial hyperthyroidism, and two years later transformation of thyroid adenoma complicated with hyperthyroidism (nodule: $6 \times 4 \times 3 \mathrm{~cm}$ ), suggesting an initiating role of thyroxine on neoplasm and a wide variety of metabolic effects, for instance, increased lipogenesis and hair growth [112]. In addition, the transformation of culture cells by radiation is in vitro facilitated by thyroid hormone [113] (Figure 6).

In vivo, mice expressing THRalphal specifically in the intestinal epithelium in wild-type THR alpha1 presented mucosal architecture and increased cell proliferation and develops adenoma at low rate [114]. This phenotype is due to cooperation between the activated THRal and WNT pathways [115]. Mutation of thyroid hormone receptor-beta (THRbeta) in mice promotes the development of mammary hyperplasia via aberrant activation of STAT5 [116]. THRbeta mutants can also induce spontaneous development of follicular thyroid carcinoma (FTC) similar to human cancer in a knocking mouse model harboring a mutated THRbeta (Thrb, denoted PV) [117-119], and thyroid hormone play a critical role in promoting thyroid carcinogenesis of Thrb (PV/PV) mice via PI3K-AKT-betaCatenin signaling pathway [120]. Moreover, southern analysis revealed a rearrangement of oncogenic THRA1/BTR fusion in the BT474 breast cancer cell line [121]. This rearrangement represented a deletion of THRA1 allele that was coamplified with ERBB2 in breast cancer.

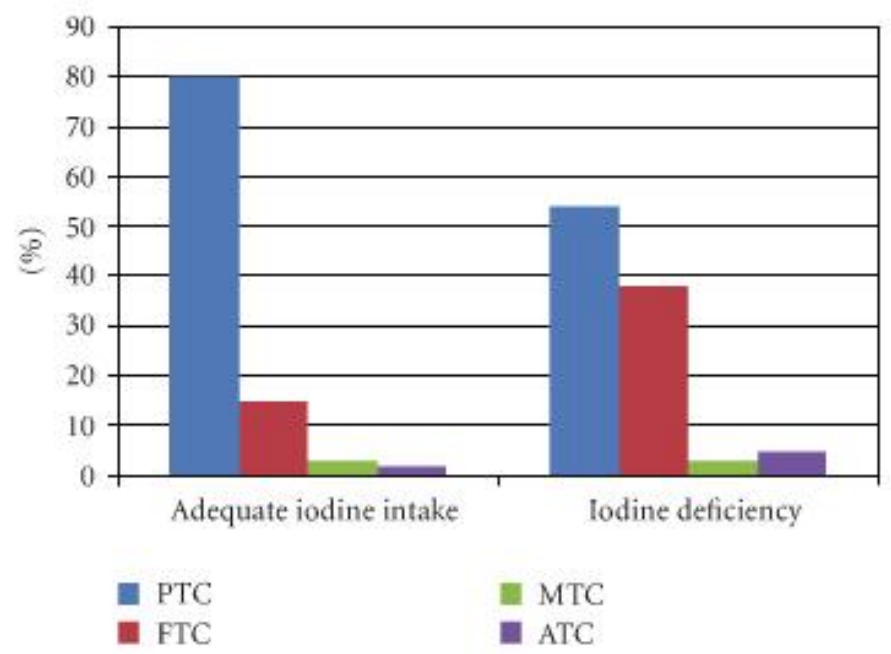

Figure 5. Contribution of iodine in the food to the thyroid tumorigenesis (Data from Giusti $\mathrm{F}$, et al. [83])

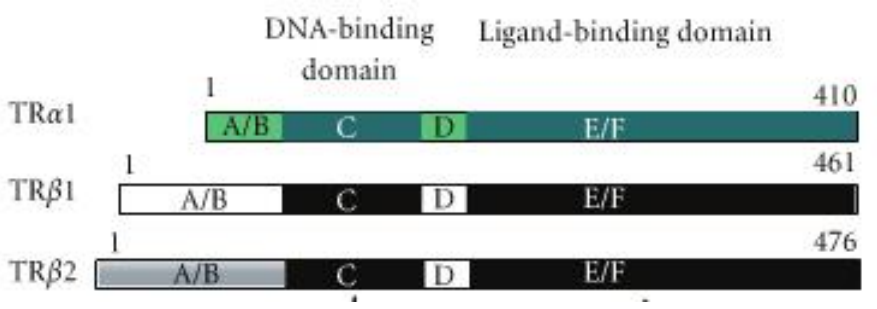

Figure 6. Structure of two thyroid hormone receptors (Data from Rosen M \& Privalsky $\mathrm{M}[114])$
In clinics, almost $63 \%$ of 16 papillary thyroid carcinoma (PTC) were found to have mutations in THRal, and a remarkable $94 \%$ in THRbeta 1 , in contrast $22 \%$ and $11 \%$ of thyroid adenomas harboring mutations in these isoforms respectively, and no mutations were found in normal thyroid controls, which implicate the differential effects of normal and oncogenic thyroid hormone receptor [122] signaling in PTC and normal health controls [123]. The findings suggest a possible oncogenic action for thyroid hormone receptor mutation in the tumorigenesis of human thyroid carcinoma [124]. Others, anaplastic thyroid cancers harbor novel oncogenic mutations of ALK gene [125]. Oncogenic receptor ALK belongs to an insulin receptor (IR) or oncogenic receptor IGF-1R family [126]. TLR4 stimulation with its ligand lipopolysaccharides promotes KSHV- induced cellular transformation and tumorigenesis by activating the STAT3 pathway [127]. Toll-like receptor (TLR4) induced pro-oncogenic function in head and neck carcinoma [128]. More others, CLIC1 was identified as a novel dominant pro-oncogenic receptor from proteomic profiling of pleomorphic human sarcoma [129]. Thus, an extensive study of thyroid hormone receptor (THR) mutations in oncogenic signaling, TSH/TSHR in thyroid disease and thyroid cancer, and also its target therapy $[130,131]$ is further perspective.

\section{References}

1. Kendall EC (1919) Isolation of the iodine compound which occurs in the thyroid. $J$ Biol Chem 39: 125-147.

2. Knobel M, Medeiros-Neto G (2007) Relevance of iodine intake as a reputed predisposing factor for thyroid cancer. Arq Bras Endocrinol Metabol 51: 701-712.

3. World Health Organization (2007) United Nations Children's Fund, International Council for the Control of Iodine Deficiency Disorders. 3rd ed. Geneva: World Health Organization.

4. Rousset B, Dupury C, Miot F, Dumont J (2015) Thyroid hormone synthesis and secretion. In: De Groot LJ, et al. Thyroid disease manager, endotext.

5. Goldberg RC, Chaikoff IL (1951) Development of thyroid neoplasm in rat following single injection of radioactive iodine. Proc Soc Exper Biol Med 76: 563-566.

6. Goldberg RC, Chaikoff IL (1952) Induction of thyroid cancer in the rat by radioactive iodine. AMA Arch Pathol 53: 22-28. [Crossref]

7. Sellers EA, Hill JM, Lee RB (1953) Effect of iodide and thyroid on the production of tumors of the thyroid and pituitary by propylthiouracil. Endocrinology 52: 188-203. [Crossref]

8. Axelrad AA, Leblond CP (1955) Induction of thyroid tumors in rats by a low iodine diet. Cancer 8: 339-367. [Crossref]

9. Yamashita H, Noguchi S, Murakami N, Kato R, Adachi M, et al. (1990) Effects of dietary iodine on chemical induction of thyroid-carcinoma. Acta Pathol Japan 40: 705-712.

10. Kanno J, Onodera H, Furuta K, Maekawa A, Kasuga T, et al. (1992) Tumor-promoting effects of both iodine deficiency and iodine excess in the rat-thyroid. Toxicol Pathol 20: 226-235.

11. Beltze C, Brabant G, Dralle H, Gerlach R, Roessner A, et al. (2002) Radiation-induced thyroid carcinogenesis as a function of time and dietary iodine supply:An in vivo model of tunorigenesis in the rat. Endocrinology 143: 2584-2592.

12. Zimmermann MB, Galetti V (2015) Iodine intake as a risk factor for thyroid cancer: a comprehensive review of animal and human studies. Thyroid Research 8: 8 .

13. McTiernan AM, Weiss NS, Daling JR (1984) Incidence of thyroid cancer in women in relation to previous exposure to radiation therapy and history of thyroid disease. J Natl Cancer Inst 73: 575-581. [Crossref]

14. Schneider AB, Shore-Freedman E, Weinstein RA (1986) Radiation-induced thyroid and other head and neck tumors:occurrence of multiple tumors and analysis of risk factors. J Clin Endocrinol Metab 63: 107-112.

15. Robbins J, Dunn JT, Bouville A, Kravchenko VI, Lubin J, et al. (2001) Iodine nutrition and the risk from radioactive iodine:a workshop report in the Chernobyl long-term follow up study. Thyroid 11: 487-491.

16. Cardis E, Kesminiene A, Ivanov V, Malakhova I, Shibata Y, et al. (2005) Risk of thyroid cancer after exposure to $131 \mathrm{I}$ in childhood. $J$ Natl Cancer Inst 97: 724-732. [Crossref] 
17. Tronko MD, Howe GR, Bogdanova TI, Bouville AC, Epstein OV, et al. (2006) A cohort study of thyroid cancer and other thyroid diseases after the Chernobyl accident:Thyroid Cancer in Ukraine detected during first screening. J Natl Cancer Inst 98: 897-903.

18. Williams D (2008) Twenty years' experience with post-Chernobyl thyroid cancer. Best Pract Res Clin Endocrinol Metab 22: 1061-1073. [Crossref]

19. Zablotska LB, Ron E, Rozhko AV, Hatch M, Polyanskaya ON, et al. (2011) Thyroid cancer risk in Belarus among children and adolescents exposed to radioiodine after Chernobyl accident. Br J Cancer 104: 181-187.

20. Hatch M, Polyanskaya O, McConnell R, Gong ZH, Drozdovitch V, et al. (2011) Urinary iodine and goiter prevalence in Belarus:experience of the Belarus-American Cohort study of thyroid cancer abd other thyroid diseases following the Chornobyl nuclear accident. Thyroid 21: 429-437.

21. Weiss W (2017) Thirty years after Chernobyl-overview of the risk of thyroid cancer,based upon the UNSCEAR scientific reports (2008-2012). Thyroid Cancer and Nuclear Accidents: Long-Term Aftereffects of Chernobyl and Fukushima.

22. Williams ED (1985) Dietary iodide and thyroid cancer. In: Hall R, Kobberling J, editors. Thyroid disorders associated with iodine deficiency and excess. New York: Raven.

23. Liu XH, Chen GG, Vlantis AC, van Hasselt CA (2009) Iodine mediated mechanisms and thyroid carcinoma. Crit Rev Clin Lab Sci 46: 302-318. [Crossref]

24. Milakovic M, Berg G, Nyström E, Lindstedt G, Gebre-Medhin M, et al. (2004) Urinary iodine and thyroid volume in a Swedish population. J Intern Med 255: 610-614. [Crossref]

25. Suzuki H, Higuchi T, Hashimoto H, Otaki S (1962) A case of endemic goiter along the seashores of Hidaka District, Hokkaido. Jpn J Med Sci Biol 51: 781-786. [Crossref]

26. Zimmermann MB, Ito Y, Hess SY, Fujieda K, Molinari L (2005) High thyroid volume in children with excess dietary iodine intakes. Am J Clin Nutr 81: 840-844. [Crossref]

27. Niepomniszcze H, Sala M, Danilowicz K, Pitoia F, Bruno O (2004) Epidemiology of palpable goiter in greater Buenos Aires, an iodine-sufficient area [corrected]. Medicina (B Aires) 64: 7-12. [Crossref]

28. Li N, Wen HY, Wang YJ, Wang ZP (2010) Study on the effects of excess iodine and excess tyrosine on goiter in mice. Inner Mongolia Med J (Chinese) 42: 1163.

29. Gao QJ, Zhang SY, Xu CL, Liu Y (2002) The dose-reaction relationship study between the goiter rate and different iodine doses in mice. Chinese Journal of Endomiology 21: 179-181.

30. Yu ZH, Ma T (1980) Iodine-excess endemic goiter. Nat Med J China 60: 475.

31. LV SM, Xu D, Chong ZS, et al. Research on factors affecting children's iodine nutrition and thyroid goiter in iodine excessive region. Chinese Journal of control of endemic disease (Chinese)

32. Zhai LP, Liu CJ, Huang FM (2007) Regional distribution of iodine excess in drinking water and its epidemiology in Jinan. Chinese Journal of public health 23: 106-107.

33. Indicators for assessing iodine deficiency disorders and their control through salt iodization. Geneva, WHO, 1994.

34. Kang TS, Lee JH, Leem D, Seo IW, Lee YJ, et al. (2012) Monitoring of iodine in foods for estimation of dietary intake. Cheongwon: National Institute of Food and Drug Safety Evaluation.

35. Dahl L, Johansson L, Julshamn K, Meltzer HM (2004) The iodine content of Norwegian foods and diets. Public Health Nutr 7: 569-576. [Crossref]

36. Falliers CJ (1960) Goiter and thyroid dysfunction following the use of iodide in asthmatic children. A.M.A.J Dis Child 99: 428

37. Oppenheimer JH, Mcpherson HT (1961) The syndrome of iodide-induced goiter and myxedema. Am J Med 30: 281-288. [Crossref]

38. Rajatanavin R, Safran M, Stoller WA, Mordes JP, Braverman LE (1984) Five patients with iodine-induced hyperthyroidism. Am J Med 77: 378-384. [Crossref]

39. Martin FIR, Tress BW, Colman PG, Deam DR (1993) Iodine-induced hyperthyroidism due to nonionic contrast radiography in elderly. Am J Med 95: 78-82.

40. Liel Y, Alkan M (1996) 'Travelers' thyrotoxicosis', Transitory thyrotoxicosis induced by iodinated preparations for water purification. Arch Intern Med 156: 807-810.

41. Stanbury JB, Ermans AE, Bourdoux P, Todd C, Oken E, et al. (1998) Iodine-induced hyperthyroidism: occurrence and epidemiology. Thyroid 8: 88-100.

42. Jonckheer MH, Velkniers B, van Haelst L, van Blerk M (1992) Further characterization of iodide-induced hyperthyroidism based on the direct measurment of intrathyroidal iodine stores. Nuclear Medicine Communication 13: 114-118.
43. Roti E, Uberti ED (2001) Iodine excess and hyperthyroidism. Thyroid 11: 493-500. [Crossref]

44. Laurberg P (2006) Increase in incidence of hyperthyroidism predominantly occurs in young people after iodine fortification of salt in Demark. J Clin Endocrinol Metab 91: 3830-3834.

45. Brotfain E, Koyfman L, Frenkel A, Smolikov A, Zlotnik A (2013) Iodine-induced hyperthyroidism - An old clinical entity that is still relevance to daily ICU practice:A case report. Case reports in endocrinology.

46. Okamura K, Inoue K, Omac T (1978) A case of Hashimoto's thyroiditis with thyroid immunological abnormality manifested after habitual ingestion of seaweed. Acta Endocrinol (Copenh) 88: 703-712.

47. Ermans AM, Camus M (1972) Modifications of thyroid function induced by chronic administration of iodide in the presence of "autonomous" thyroid tissue. Acta Endocrinol(Copenh) 70: 463-475.

48. Kopp P. Thyrotoxicosis of other etiologies. Thyroid Disease Manager (www. endotext.org).

49. Coindet J (1821) Nouvelles recherches sur les effects de l'iode,et sur les cautions survere dansle traitment du goiter par ce nuveau remide. Ann Chimie Phys 16: 252-266.

50. Vagenakis AG, Wang CA, Burger A, Maloof F, Braverman LE, et al. (1972) Iodideinduced thyrotoxicosis in Boston. N Engl J Med 287: 523-527. [Crossref]

51. Stewart JC, Vidor GI (1976) Thyrotoxicosis induced by iodine contamination of food a common unrecognized condition? Br Med J 1: 372 .

52. Todd CH, Allain T, Gomo ZA, Hasler JA, Ndiweni M, et al. (1995) Increase in thyrotoxicosis associated with iodine supplements in Zimbabwe. Lancet 346: 1563 1564. [Crossref]

53. Bürgi H, Kohler M, Morselli B (1998) Thyrotoxicosis incidence in Switzerland and benefit of improved iodine supply. Lancet 352: 1034. [Crossref]

54. Shetty KR, Duthie EH Jr (1990) Thyrotoxicosis induced by topical iodine application. Arch Intern Med 150: 2400-2401. [Crossref]

55. Becker CB, Gordon JM (1993) Iodinated glycerol and thyroid dysfunction: Four cases and a review of the literature. Chest 103: 186-192.

56. Laurberg P, Persen KM, Vestergaard H, Sigurdsson G (1991) High incidence of multinodular toxic goitre in the elderly population in a low iodine intake area vs high incidence of Grave's disease in the young in a high iodine intake area:comparative survey of thyrotoxicosis epidemiology in East-Jutland Denmark and Iceland. $J$ Intern Med 229: 415-420.

57. Galofre JC, Fernandez-Calvet L, Rios M, Garcia-Mayor RVG (1994) Increased incidence of thyrotoxicosis after iodine supplementation in an iodine sufficient area. $J$ Endocrinol Invest 17: 23-27. [Crossref]

58. Higgs M, Hull E, Lujan E (2014) A case report of post-operative Jod-Basedow phenomennon following oral and IV iodine contrast administration. Case reports in endocrinology.

59. Yagishita A, Hachiya H, Kawabata M, Nakamura T, Sugiyama K, et al. (2013) Amiodarone-induced thyrotoxicosis late after amiodarone withdrawal. Circ J 77: 28982903.

60. Mussig K, Thamer C, Bares R, Lipp HP, Haring HU, et al. (2006) Iodine-induced thyrotoxicosis after ingestion of kelp-containing tea. J Gen Intern Med 21: C11-C14.

61. Lee SM, Lewis J, Buss DH, Holcombe GD, Lawrance PR (1994) Iodine in British foods and diets. Br J Nutr 72: 435-446. [Crossref]

62. Teas J, Pino S, Critchley A, Braverman LE (2004) Variability of iodine content in common commercially available edible seaweeds. Thyroid 14: 836-841. [Crossref]

63. Ohye H, Fukata S, Kanoh M, Kubota S, Kuma K, et al. (2005) Thyrotoxicosis caused by weight-reducing herbal medicines. Arch Intern Med 165: 831-834. [Crossref]

64. Shilo S, Hirsch HJ (1986) Iodine-induced hyperthyroidism in a patient with a normal thyroid gland. Postgrad Med J 62: 661-662. [Crossref]

65. DeSmet PA, Stricker BH, Wilderiok F, Wiersinga WM (1990) Hyperthyroidism during treatment with kelp tablets. Ned Tijdschr Geneesk 134: 1373.

66. Salas Coronas J, Cruz Caparrós G, Laynez Bretones F, Díez García F (2002) [Hyperthyroidism secondary to kelp tablets ingestias]. Med Clin (Barc) 118: 797-798. [Crossref]

67. Picco G, de Dios-Romero A, Albanell N, Badia J (2006) [Regular intake of seaweed and hyperthyroidism]. Med Clin (Barc) 127: 199. [Crossref] 
68. Eliason BC (1998) Transient hyperthyroidism in a patient taking dietary supplements containing kelp. J Am Board Fam Pract 11: 478-480.

69. Ishizuki Y, Yamauchi K, Miura Y (1989) Transient thyrotoxicosis induced by Japanese kombu. Nippon Naibunpi Gakkai Zasshi 65: 91-98.

70. Zhu G, Musumeci F, Byrne P (2013) Induction of thyroid neoplasm following plant medicone marine algae (sargassum): A rare case and review of the literature. Curr Pharm Biotechnol 14: 859-863.

71. Choi WJ, Kim J (2014) Dietary factors and the risk of thyroid cancer: a review. Clin Nutr Res 3: 75-88. [Crossref]

72. Schneider DF, Chen H (2013) New developments in the diagnosis and treatment of thyroid cancer. CA Cancer J Clin 63: 374-394. [Crossref]

73. Michikawa T, Inoue M, Shimazu T, Sawada N, Iwasaki M, et al. (2012) Seaweed consumption and the risk of the thyroid cancer in women:the Japan Public Health Center-based prospective study. Eur J Cancer Pre 21: 254-260.

74. Franceschi S (1998) Iodine intake and thyroid carcinoma--a potential risk factor. Exp Clin Endocrinol Diabetes 106 Suppl 3: S38-44. [Crossref]

75. Feldt-Rasmussen U (2001) Iodine and cancer. Thyroid 11: 483-486. [Crossref]

76. Horn-Ross PL, Morris JS, Lee M, West DW, Whittemore AS, et al. (2001) Iodine and thyroid cancer risk among women in a multiethnic population: The Bay Area Thyroid Cancer Study. Cancer Epidemiol Biomarkers Prev 10: 979-985. [Crossref]

77. Kolonel LN, Hankin JH, Wilkens LR, Fukunaga FH, Hinds MW (1990) An epidemiologic study of thyroid cancer in Hawaii. Cancer Causes Control 1: 223-234. [Crossref]

78. Niedziela M, Korman E (2003) Risk of neoplasm in autoimmune thyroid disease in children-transition from iodine deficiency to iodine sufficiency. 42nd Annual Meeting ESPE: Miniposters, 15 (MP2-5/P1-380) Ljublijana (Slovenia).

79. Chandrasekaran M, Ramadevi K (2013) Thyromegaly and iodine nutritional status in a tertiary care hospital in South India. Indian J Endocrinol Metab 17: 260-264. [Crossref]

80. Gu WL, Wu HS, Liang LS, et al. (2010) A retrospective survey of 8004 thyroid following post-operative evaluation. Guangdong Medical Journal (chinese) 31: 1990-1992

81. Cui JS, Ni JS, Kong QY, Wang J (2008) Analysis of detection rate of thyroid malignant tumor before and after universal salt iodization and histilogical types. J Gilin Univ (medicine edition).

82. Guan HX, Shan ZY, Mi XY, Wang EH, Teng WP (2006) Incidence of thyroid carcinoma before and after universal salt iodization in 11-year retrospective analysis of pathological reports. J Chin Med Univ (chinese) 35: 284-285.

83. Giusti F, Falchetti A, Franceschelli F, Marini F, Tanini A, et al. (2010) Thyroid cancer: current molecular perspectives. J Oncol 2010: 351679.

84. Netea-Maier RT, Aben KKH, Caspaie MK, den Heijer M, Grefle JMM, et al. (2008) Trends in incidence and mortality of thyroid carcinoma in The Netherlands between 1989 and 2003: Correlation with thyroid fine-needle aspiration cytology and thyroid surgery. Int J Cancer 123: 1681-1684.

85. Rego-Iraeta A, Perez-Mendez LF, Mantinan B, Garcia-Mayor RV (2009) The trends for thyroid cancer in northwestern Spain:true rise in the incidence of micro and larger forms of papillary thyroid carcinoma. Thyroid 19: 333-340.

86. Belfiore A, La Rosa GL, La Porta GA, Giuffrida D, Milazzo G, et al. (1992) Cancer risk in patients with cold thyroid nodules: relevance of iodine intake, sex, age, and multinodularity. Am J Med 93: 363-369. [Crossref]

87. Fukunaga FH, Lockett LJ (1971) Thyroid carcinoma in the Japanese in Hawaii. Arch Pathol 92: 6-13. [Crossref]

88. Fukunaga FH, Yatani R (1975) Geographic pathology of occult thyroid carcinomas. Cancer 36: 1095-1099. [Crossref]

89. Sampson RJ, Woolner LB, Bahn RC, Kurland LT (1974) Occult thyroid carcinoma in Olmsted County, Minnesota: Prevalence at autopsy compared with that in Hiroshima and Nagasaki, Japan. Cancer 34: 2072-2076.

90. Yamamoto Y, Maeda T, Izumi K, Otsuka H (1990) Occult papillary carcinoma of the thyroid - a study of 408 autopsy cases. Cancer 65: 1173-1179.

91. Kolonel LN, Hankin JH, Wilkens LR, Fukunaga FH, Hinds MW (1990) An epidemiologic study of thyroid cancer in Hawaii. Cancer Causes Control 1: 223-234. [Crossref]

92. Pan Y, Caldwell KL, Li Y, Caudill SP, Mortensen ME, et al. (2013) Smoothed urinary iodine percentiles for the US population and pregnant women:National Health and Nutrition examination survey, 2001-2010. Eur Thyroid J 2: 127-134.
93. Lubitz CC, Kong CY, MeMahon PM, Daniels GH, Chen YF, et al. (2014) Annual financial impact of well-differentiated thyroid cancer care in the United States. Cancer 120: $1345-1352$.

94. Pettersson B, Coleman MP, Ron E, Adami HO (1996) Iodine supplementation in Sweden and regional trends in thyroid cancer incidence by histopathologic type. Int J Cancer 65:13-19.

95. Rasmussen LB, Jorgensen T, Perrild H, Knudsen N, Krejbjerg A, et al. (2014) Mandatory iodine fortification of bread and salt increases iodine excretion in adults in Denmark- a 11-year follow-up study. Clin Nutr 33: 1033-1040.

96. Sehestedt T, Knudsen N, Perrild H, Johansen C (2006) Iodine intake and incidence of thyroid cancer in Denmark. Clin Endocrinol (Oxf) 65: 229-233. [Crossref]

97. Williams ED, Doniach I, Bjarnason O, Michie W (1977) Thyroid cancer in an iodide rich area: a histopathological study. Cancer 39: 215-222. [Crossref]

98. Hofstadter F (1980) Frequency and morphology of malignant tumors of the thyroid before and after the introduction of iodine-prophylaxis. Vichows Arch A Pathol Anat Histol 385: 263-270.

99. Teng W, Shan Z, Teng X, Guan H, Li Y, et al. (2006) Effect of iodine intake on thyroid diseases in China. N Engl J Med 354: 2783-2793. [Crossref]

100. Harach HR, Ceballos GA (2008) Thyroid cancer,thyroiditis and dietary iodine:a review based on the Salta,Argentina model. Endocr Pathol 19: 209-220.

101. Galanti MR, Hamsson L, Bergstrom R, Wolk A, Hjartaker A (1997) Diet and the risk of papillary and follicular thyroid carcinoma:a population-based case-control study in Sweden and Norway. Cancer Causes Control 8: 205-214.

102. Bandurska-Stankiewicz E, Aksamit-Bialosewska E, Rutkowska J, Stankiewicz A, Shafie D (2011) The effect of nutritional habits and addiction on the incidence of thyroid carcinoma in the Olsztyn province of Poland. Endokrynol Pol 62: 145-150.

103. Truong T, Baron-Dubourdieu D, Rougier Y, Guenel P (2010) Role of dietary iodine and cruciferous vegetables in thyroid cancer:a countrywide case-control study in New Caledonia. Cancer Causes Control 21: 1183-1192

104. Memon A, Varghese A, Suresh A (2002) Benign thyroid disease and dietary factors in thyroid cancer: a case-control study in Kuwait. Br J Cancer 86: 1745-1750. [Crossref]

105. Ciosek J, Drobnik J (2004) Vasopressin and oxytocin release and the thyroid function. J Physiol Pharmacol 55: 423-441. [Crossref]

106. Borck C, Guerney DL, Edelman IS (1983) Critical role played by thyroid hormone in induction of neoplastic transformation by chemical carcinogen in tissue culture. Proc Natl Acad Sci USA 80: 5749-5752.

107. Huang YH, Li YH, Chi HC, Liao CH, Liao CJ, et al. (2013) Thyroid hormone regulation of miR-21 enhances migration and invasion of hepatoma. Cancer Res 73: 1.

108. Shapiro SJ, Friedman NB, Perzik SL, Catz B (1970) Incidence of thyroid carcinoma in Graves' disease. Cancer 26: 1261-1270. [Crossref]

109. Hancock BW, Bing RF, Dirmikis SM, Munro DS, Neal FE (1977) Thyroid carcinoma and concurrent hyperthyroidism: a study of ten patients. Cancer 39: 298302. [Crossref]

110. Livadas D, Psarras A, Koutras DA (1976) Malignant cold thyroid nodules in hyperthyroidism. Br J Surg 63: 726-728. [Crossref]

111. Lin LS, Chen TS, Chen MC (1984) Thyroid carcinoma and concurrent hyperthyroidim and/or Hashimoto's thyroiditis. Chin J Intern Med (chinese) 23: 91-94.

112. Zong GX,Tong ZK (1982) Toxic nodular goiter complicate with alopecia:a case report. Chin J Intern Med (chinese) 21: 526.

113. Guernsey DL, Ong A, Borck C (1980) Thyroid hormone modulation of x ray-induced in vitro neoplastic transformation. Nature 288: 891.

114. Rosen M, Privalsky M (2011) Thyroid hormone receptor mutations in cancer and resistance to thyroid hormone:perspective and prognosis. Journal of Thyroid Research 2011: 361304.

115. Kress E, Skah S, Siratov M, Nadjar J, Gadot N, et al. (2010) Cooperation between the thyroid hormone receptor TRalphal and WNT pathway in the induction of intestinal tumorigenesis. Gastroenterology 138: 1863-1874.

116. Guigon CJ (2011) Mutation of thyroid hormone receptor-beta in mice predispose to the development of mammary tumors. Oncogene 30: 3381-3390.

117. Guigon CJ, Cheng SY (2009) Novel oncogenic actions of TRbeta mutants in tumorigenesis. IUBMB Life 61: 528-536. [Crossref] 
118. Suzuki H, Willingham MC, Cheng SY (2002) Mice with a mutation in the thyroid hormone receptor beta gene spontaneously develop thyroid carcinoma: a mouse model of thyroid carcinogenesis. Thyroid 12: 963-969.

119. Lu C, Mischra A, Zhu YLJ, Meltzer P (2011) Global expression profiling reveals gain-of-function oncogenic activity of a mutated thyroid hormone receptor in thyroid carcinogenesis. Am J Cancer Res 1: 168-191.

120. Lu C (2012) Activation of tumor cell proliferation by thyroid hormone in a mouse model of follicular thyroid carcinoma. Oncogene 31: 2007-2016.

121. Futreal PA (1994) Mutation analysis of the THRA1 gene in breast cancer:deletion fusion of the gene to a novel sequence on $17 \mathrm{q}$ in the BT474 cell line. Cancer Res 54: 1791-1794.

122. Judeson C, Privalsky ML (1996) DNA recognition by normal and oncogenic thyroid hormone receptor,unexpected diversity in half-site specificity controlled by non-zincfinger determinants. J Bio Chem 271: 10800-10805.

123. Puzianowska-Kuznicka M, Krystyniak A, Madej A, Cheng SY, Nauman J (2002) Functionally impaired TR mutants are presented in thyroid papillary cancer. $J$ Clin Endocrinol Metab 87: 1120-1128.

124. Cheng SY (2013) Thyroid hormone receptor mutations in cancer. Molecular and Cellular Endocrinology 23: 30.
125. Murugan AK, Xing M (2011) Anaplastic thyroid cancers harbor novel oncogenic mutations of the ALK gene. Cancer Res 71: 4403-4411.

126. Zong CS, Zeng L, Jiang Y, Sadowski HB, Wang LH (1998) Stat3 plays an important role in oncogenic ROS- and insulin-like growth factor 1 receptor-induced anchorageindependent growth. J Biol Chem 273: 28065-28072.

127. Gruffaz M, Vasan K, Tan B, Ramos da Silva S, Gao SJ, et al. (2017) TLR4-mediated inflammation promotes KSHV-induced cellular transformation and tumorigenesis by activating the STAT3 pathway. Cancer Res 2017.

128. Ren G, Hu J, Wang R, Han W, Zhao M, et al. (2014) Rapamycin inhibits Tolllike receptor 4-induced pro-oncogenic function in head and neck squamous cell carcinoma. Oncol Rep 31: 2804-2810. [Crossref]

129. Murray E, Hernychova L, Scigelova M, Ho J, Nekulova M, et al. (2014) Quantitative proteomic profiling of pleomorphic human sarcoma identifies CLIC1 as a dominant pro-oncogenic receptor expressed in diverse sarcoma types. Journal of Proteome Research 13: 2543-2559.

130. Zhu G, Saboor-Yaraghi AA, Yarden Y, Santos J, Neil JC (2016) Downregulating oncogenic receptor: From bench to clinic. Hematol Med Oncol 1: 30-40.

131. Zhu G, Saboor-Yaraghi AA, Yarden Y (2017) Targeting oncogenic receptor From molecular physiology to currently the standard of target therapy. Advance Pharmaceutical Journal 2: 10-28.

Copyright: $(02017$ Zhu G. This is an open-access article distributed under the terms of the Creative Commons Attribution License, which permits unrestricted use, distribution, and reproduction in any medium, provided the original author and source are credited. 